\title{
Emperipolesis and cell death in NOD2-related Blau Syndrome and Crohn's disease
}

\author{
Carl El Janssen ${ }^{1 *}$, Carlos D Rose ${ }^{2}$, Antonio Naranjo ${ }^{3}$, Brigitte Bader-Meunier $^{4}$, Rolando Cimaz ${ }^{5}$, Miroslav Harjacek ${ }^{6}$,

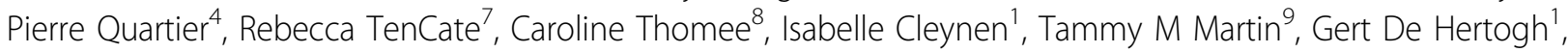 \\ Tania Roskams ${ }^{1}$, Valeer J Desmet ${ }^{1}$, Carine H Wouters $^{1}$
}

From 18th Pediatric Rheumatology European Society (PReS) Congress

Bruges, Belgium. 14-18 September 2011

\section{Background}

Blau Syndrome (BS), a rare autoinflammatory disease characterized by non-caseating granulomas, is caused by gain-of-function mutations in NOD2. Crohn's disease $(C D)$ is associated with intestinal granulomas, and SNPs in NOD2. Emperipolesis, the inside round about wandering' of lymphocytes within other cells is a typical feature of Rosai-Dorfman disease, and seen occasionally in malignancies. Cell survival and cell death are possible outcomes for both the engulfed and engulfing cells.

\section{Aim}

To investigate emperipolesis and cell death in BS and CD granulomas.

\section{Methods}

Morphological and immunohistochemical study of granulomas was undertaken in $8 \mathrm{BS}$ and 7 pediatric $\mathrm{CD}$ biopsies, using $H \& E$ and immunohistochemistry for leukocyte markers (CD68, CD4, CD8, CD20), cytokines (IFN $\gamma$, IL6, IL10, IL17, TGF $\beta$, TNF $\alpha$ ) and death-proteins (Bcl2, Fas, FasL, activated caspase 3).

\section{Results}

All BS biopsies showed polycyclic granulomas with large lymphocytic coronas and extensive emperipolesis of lymphocytes within multinucleated giant cells (MGCs). This was associated with macrovesicular/microvesicular degeneration of lymphocytes inside MGCs (Fig1a), and MGC death (Fig1b). Emperipolesis selectively involved

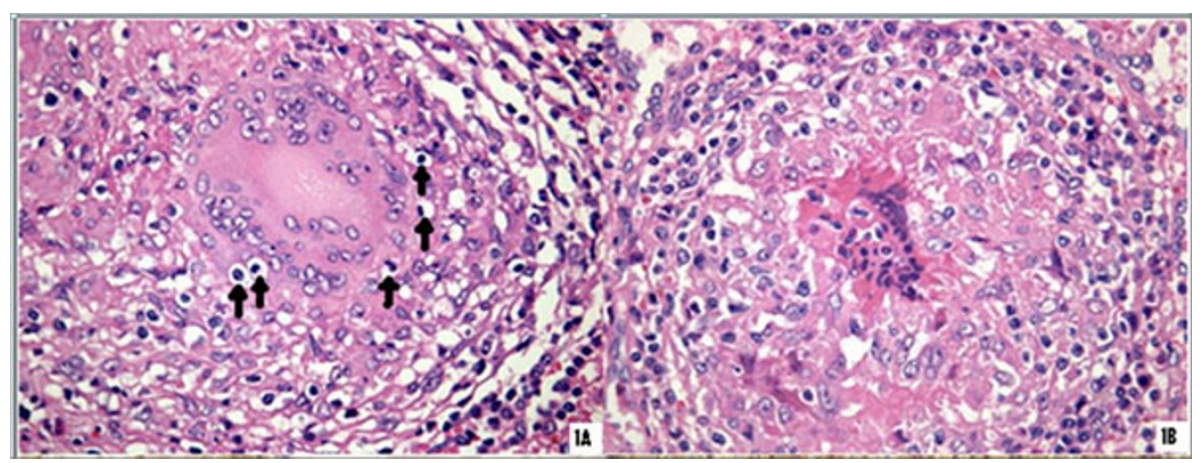

Figure 1

* Correspondence: Carljanssen39@hotmail.com

1 Leuven Univesity Hospital, Belgium

Full list of author information is available at the end of the article 
CD4+ $\mathrm{T}$ cells. In addition, vesicles and degenerative remnants inside MGCs stained strongly for IL-6 and IL-17. A moderate expression of Bcl2 was present, Fas and FasL expression were seen in emperipoletic lymphocytes and MGCs but caspase 3 was virtually absent. In contrast, $\mathrm{CD}$ biopsies demonstrated simple isolated granulomas with subtle lymphocytic coronas; emperipolesis was sporadically found in a few biopsies, and was associated with crystalline inclusions, but not with MGC death.

\section{Conclusion}

Emperipolesis of $\mathrm{CD} 4+$ lymphocytes is an important feature of BS and is associated with MGC death. NOD2 mutations causing NF- $\kappa \mathrm{B}$ hyperactivation and influencing autophagy pathways may be involved. In CD with NOD2-SNPs, emperipolesis is exceptional and crystalline inclusions are present. (Figure 1)

\section{Author details}

'Leuven Univesity Hospital, Belgium. ${ }^{2}$ DuPont Children's Hospital, Wilmington, US. ${ }^{3}$ Hospital Universitario de Gran Canaria, Spain. ${ }^{4}$ Hôpital Necker, Paris, France. ${ }^{5} \mathrm{AOU}$ Meyer and University of Florence, Italy. ${ }^{6}$ University Hospital Zagreb, Croatia. 'Leiden University Medical Center, The Netherlands. ${ }^{8}$ Centre Hospitalier Luxembourg. ${ }^{9}$ Casey Eye Institute, Portland, Oregon.

Published: 14 September 2011

doi:10.1186/1546-0096-9-S1-P293

Cite this article as: Janssen et al:: Emperipolesis and cell death in NOD2related Blau Syndrome and Crohn's disease. Pediatric Rheumatology 2011 9(Suppl 1):P293.

\section{Submit your next manuscript to BioMed Central} and take full advantage of:

- Convenient online submission

- Thorough peer review

- No space constraints or color figure charges

- Immediate publication on acceptance

- Inclusion in PubMed, CAS, Scopus and Google Scholar

- Research which is freely available for redistribution

Submit your manuscript at www.biomedcentral.com/submit 